\title{
PENAMBAHAN ENZIM FITASE DALAM PAKAN KONVENSIONAL TERHADAP PERFORMANS, PEMANFAATAN FOSFOR DAN INCOME OVER FEED COST (IOFC) AYAM BROILER
}

\section{*The Effect Of Phytase Enzyme In Conventional Diet On Body Weight Gain Of Chicken, Phosphorus Utilization And Income Over Feed Cost Of Broiler Chickens}

\author{
Idaman K. Manik ${ }^{1}$, Ma'ruf Tafsin ${ }^{2}$, dan Tri Hesti Wahyuni ${ }^{2}$ \\ 1. Mahasiswa Program Studi Peternakan Fakultas Pertanian Universitas Sumatera Utara \\ 2. Staf Pengajar Program Studi Peternakan Fakultas Pertanian Universitas Sumatera Utara
}

\begin{abstract}
This research aimed to determine the effect of phytase enzyme in conventional diet on body weight gain of chicken, Income Over feed Cost and phosphorus utilization in broiler chicken. The research was conducted in Biology Laboratory, from November to Desember 2015. The design experiment used Completly Random Design (CRD). The treatment that given phytase doses (FTU/kg feed) on this research consist of 0 (P0), 500 (P1), 1000 (P2), 1500 (P3) and 2000 (P4). The variable that observed are feed consumption, daily body weight gain, feed convertion ratio and phosphorus of utilization.The result showed that the utlilization of fitase up to $2000 \mathrm{FTU} / \mathrm{kg}$ had no significantly effect $(P>0,05)$ on feed consumption, body weight gain and feed convertion ratio. but gave significantly effect $(P<0,01)$ on utilization of posphor in diet, unifority of body weight gain and Income Ove Feed Cost. The conclusion of this research that enzime phytase be use to level 1000 FTU/kg in feed increase posphor utilization, the uniformity of body weight, the Income Over Feed Cost of broiler chicken.
\end{abstract}

Keywords : phytat acid, phytase enzyme, performances, phospor, broiler chicken

\begin{abstract}
ABSTRAK
Penelitian dilaksanakan di Laboratorium Biologi, pada bulan November-Desember 2015. Rancangan yang digunakan adalah rancangan acak lengkap (RAL). Perlakuan yang diberikan dengan dosis fitase (FTU). Dalam penelitian ini terdiri dari 0 FTU/kg ransum $\left(\mathrm{P}_{0}\right), 500 \mathrm{FTU} / \mathrm{kg}$ ransum $\left(\mathrm{P}_{1}\right), 1000 \mathrm{FTU} / \mathrm{kg}$ ransum $\left(\mathrm{P}_{2}\right), 1500 \mathrm{FTU} / \mathrm{kg}$ ransum $\left(\mathrm{P}_{3}\right)$ dan $2000 \mathrm{FTU} / \mathrm{kg}$ ransum $\left(\mathrm{P}_{4}\right)$. Parameter yang diteliti adalah konsumsi ransum, pertambahan bobot badan harian, Feed Convertion Ratio (FCR) dan pemanfaatan fosfor, keseragaman PBB dan Income over feed cost (IOFC).Hasil penelitian menunjukkan bahwa penambahan enzim fitase sampai level $2000 \mathrm{FTU} / \mathrm{kg}$ dalam ransum tidak memberikan pengaruh yang tidak berbeda nyata $(\mathrm{P}>0,05)$ terhadap konsumsi ransum, pertambahan bobot badan dan FCR. Tetapi memberikan pengaruh yang sangat nyata $(\mathrm{P}<0,01)$ terhadap pemanfaatan fosfor didalam pakan konvensional dan keseragaman pertambahan bobot badan dan Icome Over Feed Cost (IOFC) ayam broiler. Kesimpulan dari penelitian ini adalah penambahan enzim fitase sampai level $1000 \mathrm{FTU} / \mathrm{kg}$ dalam ransum mempengaruhi peningkatkan pemanfaatan fosfor dalam pakan konvensional dan meningkatkan keseragaman pertambahan bobot badan ayam broiler.
\end{abstract}

Kata kunci : Asam Fitat, Enzim Fitase, Performans, fosfor dan ayam broiler 


\section{PENDAHULUAN}

Kebutuhan protein hewani sangat diperlukan dalam menunjang aktivitas manusia, kebutuhan protein hewani ini dapat berasal dari sapi, ikan, telur, susu dan daging ayam (ayam kampung dan ayam broiler). Saat ini di Indonesia khususnya di Sumatera Utara perusahaan ternak ayam broiler sangat berkembang pesat dengan tujuan untuk memenuhi kebutuhan protein hewani masyarakat di Sumatera Utara karena harga jual ayam broiler ini relatif murah di pasar tetapi kandungan gizinya tidak kalah dengan ayam kampung.

Selain harganya yang murah, ayam broiler memiliki umur yang relatif singkat dengan lama pemeliharaan hanya sekitar 35 hari dan mampu menghasilkan daging seberat 1-2 kg. Kemampuan ayam ini untuk memproduksi daging yang relatif cepat dimanfaatkan para peternak untuk menjalankan bisnis dalam memperoleh keuntungan yang besar karena perputaran modalnya yang relatif cepat.

Penggunaan jagung dibatas karena jagung mengandung asam fitat 0,29\% (Anggorodi, 1995), sehingga dapat menghalangi proses pembentukan energi dan metabolisme yang menyebabkan zat-zat lainya kurang dapat dimanfaatkan oleh tubuh ternak. Dedak padi merupakan bahan pakan potensial dan telah banyak digunakan dalam ransum ternak, tetapi pemanfaatannya dalam ransum ayam broiler masih dibatasi sampai $15 \%$. Keterbatasan penggunaan dedak padi pada ransum ayam broiler disebabkan oleh adanya anti nutrisi berupa asam fitat. Bahan pakan yang umum digunakan dalam penyusunan ransum unggas adalah jagung, dedak, tepung ikan, bungkil kedelai, minyak sayur, bungkil kelapa, tepung kapur, batuan phosfat, asam amino sintetis (terutama metionin dan lysin) dan campuran vitamin dan mineral.

Ransum konvensional memiliki zat antinutrisi yang merugikan para peternak yang mampu menurunkan produksi dari ayam broiler, terutama di dalam bahan pakan biji-bijian mengandung zat antinutrisi asam fitat yang mengikat mineral fosfor. Zat anti nutrisi (fitat) sangat mempunyai efek negatif terhadap kecukupan gizi yang diserap oleh ayam broiler karena sifat asam fitat akan mengikat protein dan mineral-mineral yang berguna untuk pertumbuhan ayam broiler. Ketiadaan enzim fitase pada saluran pencernaan non ruminansia 
menyebabkan kandungan senyawa fitat tidak bisa dicerna, sehingga senyawa fitat terbuang bersama kotoran (eksreta) ke lingkungan (Shin et al., 2001). Widowati et al. (2001), menyatakan bahwa asam fitat merupakan bentuk penyimpanan Fosfor yang terbesar pada tanaman serealia, pada kondisi alami asam fitat akan membentuk ikatan baik dengan mineral yang bervalensi dua maupun protein menjadi senyawa yang sukar larut sehingga menyebabkan mineral dan protein tidak dapat diserap tubuh dan nilai cernanya menjadi rendah.

Pemanfaatan sumber fosfor dapat menghilangkan sifat zat anti-nutrisi dari bahan pakan yang mengandung asam fitat dibutuhkan fitase, sehingga fitase akan menjadi enzim yang sangat penting. Banyak penelitian menunjukkan bahwa suplementasi fitase pada pakan mampu meningkatkan penggunaan fosfor yang berikatan dengan asam fitat (Walz dan Pallauf, 2002). Aplikasi fitase ini bisa meningkatkan bioavailabilitas protein dan mineral-mineral melalui hidrolisis asam fitat dalam saluran pencernaan atau selama proses pembuatan pakan (Reddy et al., 1989).

\section{BAHAN DAN METODE PENELITIAN}

\section{Lokasi dan Waktu Penelitian}

Penelitian ini dilaksanakan di Laboratorium Biologi Ternak, Program Studi Peternakan Fakultas Pertanian Universitas Sumatera Utara dan berlangsung selama 6 minggu, dimulai dari November-Desember 2015.

\section{Bahan dan Alat Penelitian}

Day old Chick (DOC) ayam broiler sebanyak 100 ekor dengan kisaran bobot badan awal \pm 42 g/ekor. Bahan pakan penyusun ransum terdiri dari jagung, bungkil kedelai, bungkil kelapa, dedak, tepung ikan, minyak nabati, premix, enzim fitase, air minum, obat-obatan, vitamin, vaksin dan desinfektan yaitu rodalon.

Alat yang digunakan adalah kandang sebanyak 20 plot dengan ukuran p x 1 x $\mathrm{t}(1 \mathrm{x} 1 \mathrm{x}$ 0,5 meter). Tempat minum dan pakan masing-masing 20 buah, timbangan elektrik balance dan timbangan salter, alat- alat pembersih kandang (sapu lidi), ember, buku, alat tulis dan kalkulator. 


\section{Metode Penelitian}

Adapun rancangan penelitian yang digunakan adalah rancangan acak lengkap (RAL) dengan 5 perlakuan dan 4 ulangan setiap ulangan terdiri dari 5 ekor. Perlakuan yang diteliti adalah sebagai berikut:

$\mathrm{P} 0=$ Pakan konvensional ditambah enzim fitase 0 FTU $/ \mathrm{kg}$ ransum

$\mathrm{P} 1$ = Pakan konvensional ditambah enzim fitase $500 \mathrm{FTU} / \mathrm{kg}$ ransum

P2 = Pakan konvensional ditambah enzim fitase 1000 FTU/ kg ransum

P3 = Pakan konvensional ditambah enzim fitase $1500 \mathrm{FTU} / \mathrm{kg}$ ransum

P4 = Pakan konvensional ditambah enzim fitase 2000 FTU/ kg ransum

\section{Susunan Ransum yang akan digunakan pada saat penelitian}

Bahan yang digunakan jagung, dedak halus, bungkil kelapa, bungkil kedelai, tepung ikan, minyak nabati, premix dan enzim fitase. Dengan komposisi nutrisi pakan sebagai berikut :

Tabel 1. Susunan ransum

\begin{tabular}{lcc}
\hline \multirow{2}{*}{ Bahan Pakan } & \multicolumn{2}{c}{ Periode } \\
\cline { 2 - 3 } & Starter $(\%)$ & Finisher $(\%)$ \\
\hline Dedak Padi & 5 & 8 \\
Jagung & 50 & 50 \\
Bungkil Kelapa & 7 & 8 \\
Bungkil Kedelai & 25 & 25 \\
Tepung Ikan & 9 & 6 \\
Minyak Nabati & 2.9 & 2 \\
Premix & 1 & 1 \\
\hline Total & 100 & 100 \\
\hline Kandungan Nutrisi & & \\
\hline Bahan kering (\%) & 84.29 & 85.2 \\
Abu (\%) & 5.82 & 5.35 \\
EM (Kkal/Kg) & 3002.6 & 2951.3 \\
Protein Kasar $(\%)$ & 21.27 & 20.15 \\
Serat kasar(\%) & 4.54 & 4.9 \\
Lemak kasar (\%) & 4.12 & 4.36 \\
Kalsium (\%) & 0.78 & 0.63 \\
Posfor (\%) & 0.61 & 0.58 \\
\hline Besda
\end{tabular}

Berdasarkan perhitungan merujuk data table NRC (1994) 


\section{Peubah yang diukur}

1. Konsumsi ransum (g/ekor/minggu)

Konsumsi rasum dihitung setiap minggu berdasarkan selisih antara jumlah ransum yang diberikan dengan jumlah sisa ransum dan sisa ransum yang terbuang.

2. Pertambahan bobot badan (g/ekor/minggu)

Pertambahan bobot badan dihitung setiap minggu yaitu merupakan selisih antara penimbangan bobot badan akhir dengan penimbangan bobot badan awal.

\section{Konversi Ransum /FCR}

Konversi ransum dihitung dengan cara membandingkan jumlah ransum yang dikonsumsi pertambahan bobot badan yang dicapai setiap minggunya.

4. Pemanfaatan fosfor didalam ransum

Metode kuantitatif ini terdiri dari dua periode yaitu periode adaptasi dan periode pengambilan sampel. Ayam broiler umur 7 minggu dipuasakan selama 24 jam dengan maksud untuk menghilangkan ransum sebelumnya dari alat pencernaan. Air minum diberikan secara ad libitum. Setelah ayam dipuasakan, diberi ransum perlakuan masing-masing ayam sebanyak 150 gram. Kemudian feses ayam ditampung untuk mendapatkan koleksi sampel. Sampel feses dikeringkan, digiling dan kemudian dianalisis untuk mengetahui kandungan fosfornya.

\section{Income Over Feed Cost (IOFC)}

Income Over Feed Cost (IOFC) ini merupakan barometer untuk melihat seberapa besar biaya ransum yang merupakan biaya terbesar dalam usaha penggemukan ternak. IOFC diperoleh dengan menghitung selisih pendapatan usaha peternakan dengan biaya pakan. Pendapatan merupakan perkalian antara hasil produksi peternakan berupa daging dan harga jual. Jumlah ransum yang dihabiskan dikali dengan harga selama masa pembesaran hingga saat dijual. Nilai yang diperoleh dibandingkan antara pendapatan dengan biaya ransum tersebut (Siregar, 1980). 


\section{HASIL DAN PEMBAHASAN}

Hasil penelitian yang telah dilakukan menunjukkan bahwa Penambahan enzim fitase sampai level 2000 FTU/ kg dalam ransum tidak mempengaruhi konsumsi ransum, pertambahan bobot badan dan FCR ayam broiler tetapi meningkatkan pemanfaatan fosfor dalam pakan konvensional dan meningkatkan keseragaman pertambahan bobot badan ayam broiler dan meningkatkan Income Over Feed Cost (IOFC).

Tabel 2. Rekapitulasi pengaruh penambahan enzim fitase didalam ransum ayam broiler terhadap konsumsi ransum, PBB (g/ekor/minggu), FCR, keseragan PBB dan Pemanfaatan Fosfor

\begin{tabular}{cccccc}
\hline Perlakuan & Konsumsi $^{\text {tn }}$ & PBB $^{\text {tn }}$ & FCR $^{\text {tn }}$ & Keseragaman PBB & Pemanfaatan Fosfor \\
\hline P0 & $532,7 \pm 7,85$ & $321 \pm 21,12$ & $1,66 \pm 0,10$ & $93,43^{\mathrm{D}} \pm 0,43$ & $20.96^{\mathrm{D}} \pm 3.38$ \\
P1 & $532,4 \pm 10,59$ & $322,5 \pm 22,69$ & $1,65 \pm 0,11$ & $92,94^{\mathrm{D}} \pm 0,50$ & $37.75^{\mathrm{C}} \pm 3.20$ \\
P2 & $533,4 \pm 4,90$ & $340,15 \pm 11,17$ & $1,59 \pm 0,07$ & $96,71^{\mathrm{BC}} \pm 0,11$ & $40.86^{\mathrm{C}} \pm 5.08$ \\
P3 & $535,5 \pm 6,08$ & $329,18 \pm 11,42$ & $1,63 \pm 0,07$ & $96,53^{\mathrm{B}} \pm 0,12$ & $47.51^{\mathrm{B}} \pm 0.92$ \\
P4 & $535,1 \pm 8,69$ & $327,5 \pm 9,30$ & $1,64 \pm 0,06$ & $97,53^{\mathrm{A}} \pm 0,12$ & $59.53^{\mathrm{A}} \pm 9.63$ \\
\hline
\end{tabular}

Keterngan : huruf A, B,C dan D dengan superskrip yang berbeda menunjukkan perbedaan yang sangat nyata $(\mathrm{P}<0,01)$

\section{Konsumsi Ransum}

Konsumsi ransum merupakan kegiatan masuknya sejumlah unsur nutrisi yang ada dalam ransum tersebut. Secara biologis ayam mengkonsumsi pakan untuk proses hidupnya.

Hasil analisis ragam menunjukkan bahwa penambahan enzim fitase didalam ransum samapai level 2000 FTU memberikan pengaruh yang tidak nyata $(\mathrm{P}>0,05)$ terhadap konsumsi ransum ayam broiler. Hal ini disebabkan kualitas ransum yang diberikan selama penelitian tidak berbeda sehingga ketersediaan zat gizi yang digunakan sama dimana semua jenis perlakuan ransum mempunyai palatabilitas yang sama. Hasil penelitian ini sesuai dengan yang dilaporkan Kornegay et al. (1996) bahwa suplementasi enzim fitase tidak mempengaruhi konsumsi ransum. Suplementasi enzim fitase dalam ransum sampai 2000 FTU/kg ransum tidak nyata mempengaruhi rataan konsumsi ransum. Hal ini disebabkan oleh peningkatan ketersediaan fosfor bagi tubuh ternak akibat suplementasi enzim fitase. Fosfor mempunyai peran dalam metabolisme karbohidrat (Anggorodi 1994). Peningkatan metabolisme karbohidrat akan menyebabkan ternak cepat 
merasa kenyang sehingga aktivitas konsumsi terhenti. Hasil penelitian ini sesuai dengan penelitian yang dilakukan oleh Kornegay et al. (1996) menyatakan bahwa suplementasi enzim fitase ke dalam ransum kontrol negatif yang mengandung fosfor tersedia maupun fosfor total yang rendah tidak mempengaruhi konsumsi ransum.

\section{Petambahan Bobot Badan (PBB)}

Penelitian ini menunjukkan hasil PBB tertinggi terdapat pada perlakuan P2 yaitu 340,15 dan PBB terendah terdapat pada perlakuan P0 yaitu 321,00 namun setelah dilakukan analisis keragaman menunjukkan bahwa penambahan enzim fitase didalam ransum sampai level 2000 FTU memberikan pengaruh yang tidak nyata $(\mathrm{P}>0,05)$ terhadap pertambahan bobot badan ayam broiler. Pembesaran sel atau jaringan dari ayam broiler seperti yang diharapkan akan ditunjang oleh metabolisme protein yang lancar dan normal. Tillman et al. (1998) menyatakan bahwa pertambahan berat badan adalah suatu fungsi dari pertambahan jumlah sel dan perkembangan organ-organ tubuh. Pertumbuhan yang tidak seragam disebabkan oleh terjadinya gangguan metabolisme protein dan posfor didalam sistem pencernaan ayam broiler yang salah satu penyebabnya adalah asam fitat didalam ransum. Namun dalam penelitiaan ini dinilai kandungan asam fitat pada masing-masing perlakuan masih dalam batas ambang normal yang tidak mengganggu terhadap metabolisme sehingga penambahan enzim fitase dalam ransum sampai level 2000 FTU/kg ransum belum memperlihatkan dampak yang signifikan.

Penelitian ini menunjukkan bahwa penambahan enzim fitase didalam ransum tidak memberikan pengaruh yang nyata terhadap pertambahan bobot badan ayam broiler hal tersebut bertetangan dengan penyataan Setiyatwan (2007) yang melaporkan bahwa suplementasi enzim fitase sebanyak 1000 FTU/kg kedalam ransum nyata meningkatkan rataan bobot badan akhir ayam broiler yang dipelihara dari umur 1-42 hari.

Penelitian yang dilaksanakan selama 35 hari dilaboratorium biologi memberikan hasil yang lebih baik hal ini sesuai dengan hasil penelitian lainnya yang dilaporkan Augspurger et al. (2003) bahwa suplementasi enzim fitase hasil produk komersial sebesar 1000 FTU Natuphos/kg ransum memberikan hasil yang 
lebih baik pada peningkatan pertambahan bobot badan dan ketersediaan hayati mineral pada unggas dengan ransum berbahan dasar jagung dan kedelai.

Tabel 1. diatas menunjukkan bahwa penggunaan enzim fitase sampai level 2000 FTU/kg ransum memberikan pengaruh yang sangat nyata terhadap koefisien keragaman pertambahan bobot badan. Dari data diatas menunjukkan bahwa walaupun penambahan enzim fitase tidak berpengaruh nyata terhadap PBB ayam broiler tetapi penambahan enzim fitase dapat berpengaruh terhadap keseragaman pertambahan bobot badan ayam broiler sehingga bobot badan yang dihasilkan dalam periode pemeliharaan seragam. Hal ini bertujuan untuk menyeragam kan pertambahan bobot badan ayam broiler, sehingga bobot badan ayam broiler saat panen seragam.

\section{FCR (Feed Convertion Ratio)}

Hasil analisis ragam menunjukkan bahwa penambahan enzim fitase didalam ransum sampai level 2000 FTU memberikan pengaruh yang tidak nyata $(\mathrm{P}>0,05)$ terhadap FCR (Feed Convertion Ration) ayam broiler. Dalam penelitian ini efisiensi penggunaan pakan dalam meningkatkan pertambahan bobot badan harian ayam broiler terdapat pada perlakuan dengan penambahan enzim fitase 1000 FTU/kg pakan hal ini sesuai dengan pernyataan Onyango et al. (2004) menyatakan bahwa suplementasi enzim fitase sebanyak 1000 FTU/kg ke dalam ransum dapat meningkatkan pertambahan bobot badan dan efisiensi ransum. Konversi ransum terbaik diperoleh dari penambahan enzim fitase pada level 1000FTU/kg ransum, walaupun secara statistik memberikan perbedaan yang tidak nyata $(\mathrm{P}>0,05)$. Angka konversi ransum yang paling kecil diantara perlakuan ini $(1,59)$ memberikan gambaran optimalnya sistem pencernaan ayam broiler ini dalam mengubah 1 gram pakan menjadi 1 gram daging, semakin kecil angka konversi ransum menandakan ayam lebih baik dalam mengubah pakan menjadi daging dan ransum dapat dikatakan baik (Wahju,1998). Anggorodi (1995) menyatakan bahwa konversi ransum dalam saluran pencernaan banyak dipengaruhi oleh banyak faktor antara lain laju perjalanan ransum dalam saluran pencernaan, bentuk fisik ransum, komposisi ransum dan imbangan zat- zat gizi dalam ransum. 


\section{Pemanfaatan Fosfor}

Hasil analisis keragaman menunjukkan bahwa penambahan enzim fitase didalam ransum sampai level 2000 FTU memberikan pengaruh yang berbeda sangat nyata $(\mathrm{P}<0,01)$ terhadap pemanaatan fosfor didalam ransum ayam broiler.

Diagram 1. Pengaruh penambahan enzim fitase terhadap Pemanfaatan fosfor

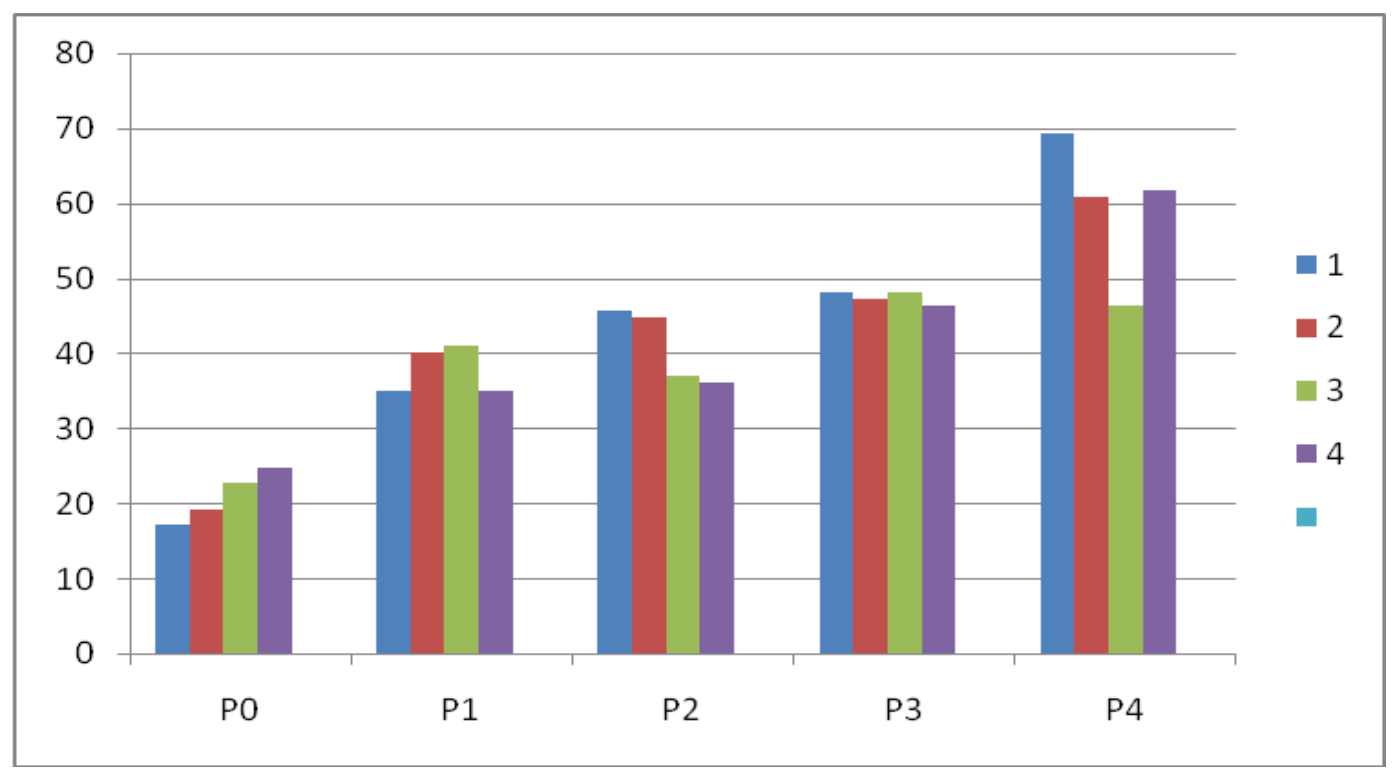

Penelitian ini menunjukkan bahwa fosfor yang paling banyak terdapat pada feses adalah perlakuan P0, sedangkan yang paling sedikit pada perlakuan P4 hal tersebut dikarenakan penambahan enzim fitase didalam ransum sehingga fosfor yang berikatan dengan asam fitat dapat dilepas dan dicerna oleh ayam broiler hal tersebut sesuai dengan pernyataan Walz dan Pallauf (2002) yang menyatakan banyak penelitian menunjukkan bahwa suplementasi fitase pada pakan mampu meningkatkan penggunaan fosfor yang berikatan dengan asam fitat. Asam fitat adalah tempat penyimpanan fosfor yang paling baik, itu dikarenakan ikatan senyawa yang terjadi antara asam fitat dengan fosfor dalam ransum yang bahan pakannya tersusun dari berbagai serealia sehingga akan menimbulkan minimnya pemanfaatan fosfor apa bila tidak ditambahkan enzim fitase didalam ransum yang banyak mengandung serealia akan mengakibatkan banyak fosfor yang terbuang ke feses hal ini sesuai dengan pernyataan Widowati et al.(2001) yang menyatakan bahwa asam fitat merupakan bentuk penyimpanan fosfor yang terbesar pada tanaman serealia, pada kondisi alami asam fitat akan membentuk ikatan baik dengan mineral yang bervalensi dua maupun protein menjadi senyawa 
yang sukar larut sehingga menyebabkan mineral dan protein tidak dapat diserap tubuh dan nilai cernanya menjadi rendah. Ketiadaan enzim fitase pada saluran pencernaan non ruminansia menyebabkan kandungan senyawa fitat tidak bisa dicerna, sehingga senyawa fitat terbuang bersama kotoran (ekskreta) ke lingkungan (Shin et al., 2000).

Hasil penelitian menunjukkan peningkatan ketersedian fosfor didalam ransum yang ditambahkah enzim fitase sampai level 2000 FTU/kg ransum hal tersebut didukung pernyataan Traylor et al., (2001), menyatakan bahwa suplementasi fitase efektif memperbaiki penggunaan dan ketersediaan $\mathrm{Ca}$ dan $\mathrm{P}$. Peningkatan ketersediaan fosfor berkorelasi positif dengan peningkatan penggunaan mineral $\mathrm{Ca}$ dan $\mathrm{Zn}$, akan tetapi ketersediaan elemen organik ini dalam jumlah tinggi akan menggangu absorpsi, retensi dan distribusi mineral tembaga.

\section{Income Over Feed Cost (IOFC)}

Income Over Feed Cost (IOFC) ini merupakan barometer untuk melihat seberapa besar biaya ransum yang merupakan biaya terbesar dalam usaha penggemukan ternak. IOFC diperoleh dengan menghitung selisih pendapatan usaha peternakan dengan biaya pakan. Pendapatan merupakan perkalian antara hasil produksi peternakan berupa daging dan harga jual. Jumlah ransum yang dihabiskan dikali dengan harga selama masa pembesaran hingga saat dijual. Nilai yang diperoleh dibandingkan antara pendapatan dengan biaya ransum tersebut (Siregar, 1980).

Diagram 2 di bawah menunjukkan bahwa Income Over Feed Cost (IOFC) tertinggi yaitu pada perlakuan P2 $(19617,14)$, kemudian diikuti perlakuan P1 $(19560,42)$, P0 $(19350,24)$, P3 $(18428,85)$, dan terendah terdapat pada perlakuan P4 (17827,56). Dari tabel di atas di ketahui bahwa perlakuan P2 lebih baik dari perlakuan P0, yang artinya penggunaan enzim didalam pakan tidak memberikan keuntungan didalam pakan konvensional. 


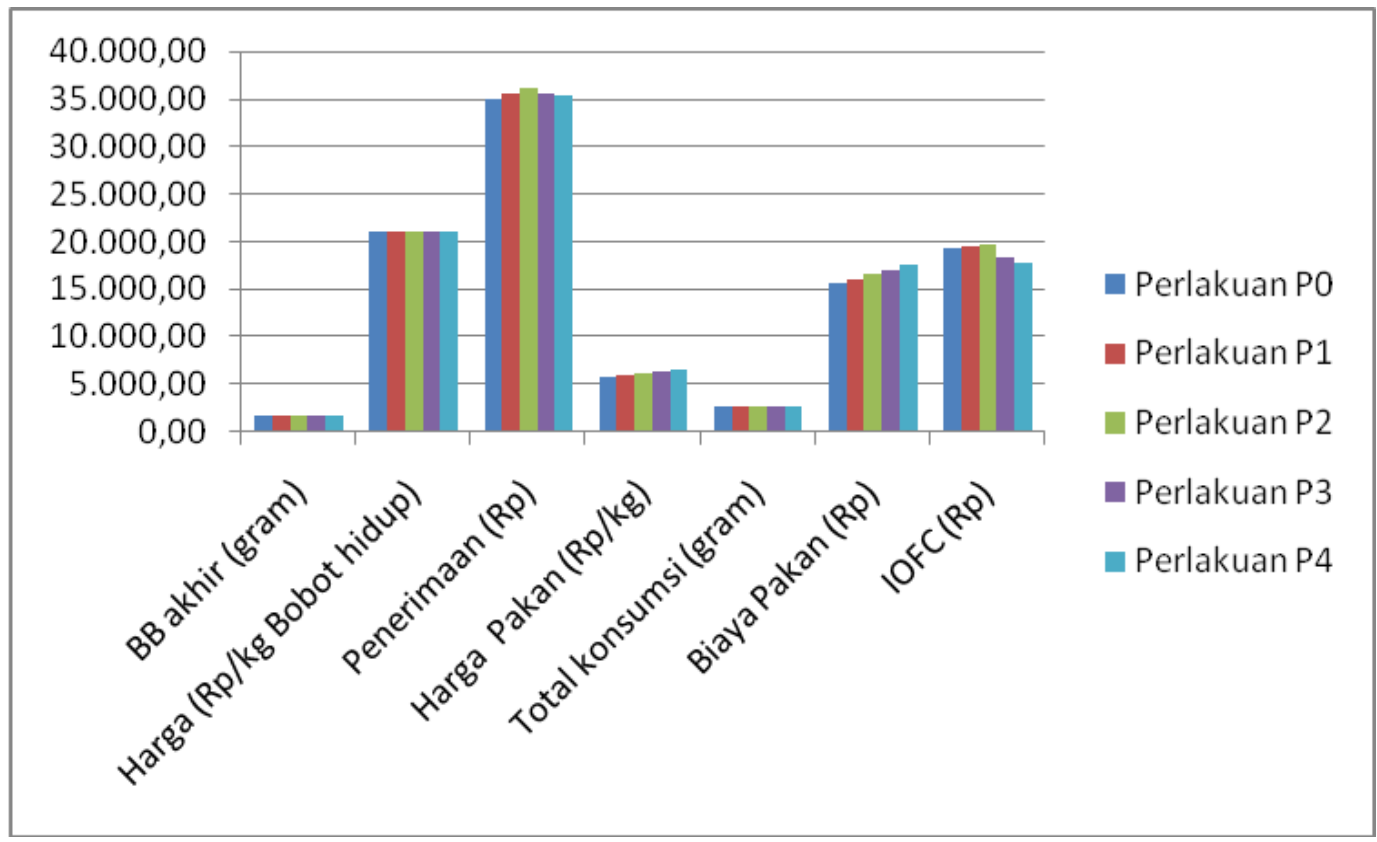

Diagram 2.pengaruh penambahn enzim fitase terhadap Income Over Feed Cost

\section{KESIMPULAN}

\section{Kesimpulan}

Penambahan enzim fitase sampai level 2000 FTU/kg dalam ransum tidak mempengaruhi konsumsi ransum, pertambahan bobot badan dan FCR ayam broiler tetapi meningkatkan pemanfaatan fosfor dalam pakan konvensional dan meningkatkan keseragaman pertambahan bobot badan ayam broiler serta meningkatkan Income over feed cost (IOFC).

\section{DAFTAR PUSTAKA}

Anggorodi, R. 1994. Ilmu Makanan Ternak Unggas. UI Press. Jakarta.

Anggorodi, H.R. 1995. Nutrisi Aneka Ternak Unggas. PT Gramedia Pustaka Utama. Jakarta

Augspurger. N. R., D. M. Webel., X.G. Lei and D. H. Baker. 2003. Efficacy of an E. Coli Phytase Expressed in Yeast for Releasing Phytate-Bound Phosphorus in Young Chick and Pigs. J. Anim. Sci. 81: 474-483.

Kornegay ET, Denbow DM, Yi Z, Ravindran V. 1996.Response of Broiler to Graded Levels of Natuphos Phytase added to Corn-Soybean MealBased Diets Containing Three Levels of Non Phytate Phosphorus. Brit J Nutr 75:839-852. 
Kusriningrum. 2008. Dasar Rancangan Percobaan dan Rancangan Acak Lengkap. Fakultas Kedokteran Hewan. Universitas Airlangga. Surabaya.

(NRC) National Research Council. 1994. Nutrient Requirements of Poultry. Ed Rev ke-9. Washington DC: Academy Pr

Onyango EM, Dilger RN, Sands JS, Adeola O. 2004. Evaluation of microbial phytase in broiler diets 1. Poult Sci 83 : 962-970.

Reddy, N. R., M. D. Pierson, S. K. Sathe, and D. K. Salunkhe. 1989. Fitates in cereals and legumes. CRC Press, Inc. Boca Raton, Florida.

Shin, S., N.C. Ha, B.C. Oh, T.K. Oh, and B.H. Oh. 2001. Enzyme mechanism and catalytic property of Bpropeller phytase. Structure.9:851-858.

Siregar, A.P. 1980. Teknik Beternak Ayam Pedaging di Indonesia. Media Group, Jakarta.

Tillman, A. D., H. Hartadi, S. Reksohadiprodjo, S.P. Kusumo dan S. Lebdosoekojo. 1998. Ilmu Makanan Ternak Dasar. Cetakan Ke enam. Gadjah Mada University Press, Yogyakarta.

Traylor SL, Cromwell GL, Lindermann MD, Kuabe DA. 2001. Effects of Levels of Suplemental Phytase on Ileal Digestibility of Amino AcidCalcium and Phosphorus in Dehulled Soybean Meal for Growing Pigs. J Anim Sci 79:2634-2642.

Wahju, J. 1988. Ilmu Nutrisi Unggas. Gadjah Mada University Press. Yogyakarta

Walz, O.P. and J. Pallauf. 2002. Microbial Phytase combined with amino acid supplementation reduce $P$ and $n$ excretion of growing and finishing pigs without loss performance.Intl. J. Food Sci. Technol. 37: 835-848.

Widowati S, Andriani D, Riyanti EI, Raharto OP, Sukarno L. 2001. Karakterisasi Fitase dari Bacillus coagulans. Prosiding Seminar Hasil Penelitian Rintisan dan Bioteknologi Tanaman. Hal.245-55. Balai Penelitian Bioteknologi Tanaman Pangan, Bogor. 